\title{
Current Status and Future Scope of Producers' Cooperatives in Livelihood Generation of Assam
}

\author{
Dr. Sangita Borah ${ }^{1}$, \\ ${ }^{I}$ Faculty Associate, Assam Rajiv Gandhi University of Cooperative Management, India
}

\begin{abstract}
Producers' Cooperatives are the backbone of the cooperative system and involved in variety of functions serving the rural masses. Assam has 312 organized Dairy Cooperative Societies, 450 nos. of Primary Fishery Cooperatives and 988 numbers of primary levels weavers' Co-operative societies functioning in the State. Performance of Sugar and Jute cooperatives were not found very successful in the state, as both the sugar mills are under liquidation and Jute mill is running under sick situation due to miss management of various activities of the societies. Area and production of sugarcane and Jute found to be increasing from 2007-08 to 2015-16 which reflects the scope of development of cooperative sugar factories and cooperative Jute mills in the state. Functional cooperative societies of Assam was observed to be continuously decreasing from 2005-06 (10134 nos) to 2012-13 (8422 nos) and Members' registration is observed to be almost stagnant throughout the period. During the period from 2005-06 to 2012-13 working capital contribution was observed to be increasing while share capital contribution was found stagnant and sometime it is observed to be decreasing. This is due to the fact that continuous Govt funding towards functional cooperative societies increasing the value of working capital while with decrease registration of members in the cooperative societies share capital was found to be decreasing.
\end{abstract}

Keywords: Producers' Cooperatives, present status, functioning, scope for improvement.

\section{INTRODUCTION}

The cooperative sector in India is the largest in the world and it plays a very important role in employment generation, poverty alleviation and ensuring food security. In Post-Independence, cooperatives assumed a great significance in poverty removal and socio-economic growth. They became an integral part of the five-year plans. As a result, they emerged as a distinct segment in the Indian economy. In Assam, Producer Cooperatives are the backbone of the cooperative system and involved in variety of functions serving the rural masses by providing fertilizers, seeds, agro-chemicals, agriculture implements, food and beverages products, milk and milk products, handloom and textiles etc. Their role has been commendable and helped in making essential inputs availability to the rural masses. Beside the Public and Private sectors, Cooperative being the third economic sector of the country playing major role in livelihood generation for rural masses.

\section{FINDING AND DISCUSSION}

\subsection{Employment in Organized Sector:}

Producers' cooperatives are playing the vital role in reflecting contribution of Cooperatives towards national economy. Most of the producers Cooperatives are actively involved with agricultural and allied activities in their livelihood generation.(1) From the Table 1, it is clearly observed that public sector contributes 17.86 million employments in the year 2010, while it was observed to be 17.67 million in the year 2008. It means that employment generation by public sector was very low from the year 2008 to 2010 . Private sector contributed only 9.87 million in the year 2008 and it was increased to 10.84 million in the year 2010. There was a huge difference between employment generation in Public and Private sector in our country. The Table 1 also reflected that Cooperative sector contributed 16.69 million employments in the year 2008 and it was increased to 17.80 million in the year 2010. The Cooperative and Public both the sectors contributed almost equal nos of employment in the country. The percentage change of employment generation in public, private and cooperative sector signifies that public sector contributed very low in employment generation (1.06 percent) as compared to private $(9.83$ percent $)$ and cooperative sector ( 6.65 percent). This implies that cooperatives are well capable of generating employment to the unemployed youth. (3) 


\subsection{Share of Cooperatives in Indian Economy:}

Table 2 reflects share of Cooperatives in Indian Economy. From the Table it is reflected that 80 percent of contribution was observed from dairy cooperatives. Warehouse cooperatives, Handlooms and Sugar cooperatives performed next to dairy cooperatives in India. The Cooperative sector gives 1.22 million direct employments and 15.4 million self employments during the year 2012 .

\subsection{Different types of cooperative societies operating with different activities include:}

- Producers' Cooperatives

- Marketing Cooperatives

- Service Cooperatives

- Allied Service Cooperatives

During the year 2015-16, there were 8835 Cooperative societies of various types working in the state. These include:

- Primary Agricultural Co-operative Societies (GPSS and LAMPS) banks

- Thrift and credit cooperatives

- Dairy cooperatives

- Farming cooperatives

- Fishermen cooperatives

- Pisciculture cooperatives,

- Consumer cooperatives

- Transport cooperatives

- Cooperative Sugar mills and spinning mills,

- Jute mills

- Housing cooperatives

- Marketing cooperatives besides many other types of co-operatives

Active Producer cooperative societies of Assam include:

- Dairy Cooperative societies

- Cooperative Fish Farming Societies

- Cooperative Sugar mill

- Cooperative Jute mill

- Weavers \& Artisan cooperative societies

\subsubsection{Dairy cooperative societies:}

India continued to be the largest milk producing nation with anticipated milk Production of 155.49 million tonnes during 2015-16. The dairy cooperatives collectively procured 15.58 million tonnes of milk registering a growth of around 12 per cent compared to last year. Liquid milk marketing by the cooperatives stood at 12.08 million tonnes with an increase of around 2.73 per cent over the previous year.(3) Assam has 312 organized Dairy Cooperative Societies performing milk business in various levels.

Few Successful Dairy cooperatives of Assam:

1. WAMUL

2. Sitajakhala Milk Cooperative Society.

3. Sundarpukhuri Dairy Cooperative Society.

2.3.1.1 WAMUL (West Assam Milk Producers' Cooperative Union Ltd):

Primary Milk Cooperatives are village level cooperatives. There are 439Nos. of Primary Milk Dairy Cooperative Societies in the State. Most of these cooperatives are the members of the Milk Unions, that is, their Federation namely, WAMUL \& EAMUL (defunct). These Cooperatives sale their surplus milk to their Union and their Federation.

Three nos of Regional level Milk Cooperative Unions had been organized namely, i.) West Assam Milk Producers Union Ltd. (WAMUL), ii) East Assam Milk Producers Cooperative Union Ltd. (EAMUL) and iii) Cachar \& Karimganj District Milk Producers Cooperative Society Ltd. (CAMUL). The management of WAMUL, EAMUL and CAMUL have been handed over to NDDB, New Delhi. The WAMUL is supplying toned milk which is popularly known as PURABI MILK, Paneer, Curd, Ghee, Lachi and Cream to its customers.(4) 


\subsubsection{Sitajakhala Milk Cooperative Society:}

It was established on $11^{\text {th }}$ June 1959 as registered cooperative society of Assam. The 'Key' village scheme and Integrated Cattle Development Project was started by the society in the year 1971 by replacing all the indigenous cattle by cross- breed jersey cows. Milk production by the society was recorded to be 12,000 13,000 lit/day. Turnover of the society in last year (2015-16) was recorded to be 28 crore. The society has 1000 registered members working actively with the society along with them directly and indirectly they have generated livelihood to 5000 to 5500 families in the current year. Value added products of the society include sweets, curd, cream etc. Selling of value added products were the main reason of increase income of the society from the year 2015-16 to 2016-17.

\subsubsection{Sundarpukhuri Dairy Cooperative Society:}

The society was established in the year 2004 in the Sivasagar district of Assam. Presently the cooperative has 245 producer members working actively with the society. Everyday 1200-1400 lit of milk collected by the society for loose sale, packed sale and for preparation of sweets, paneer and lassi etc. The society is employing 30 employees in the organization and directly and indirectly generated livelihood to the nearly 1000 families. The society is trying to increase their market to Jorhat and Dibrugarh districts within the year of 2018. The society was observed to be performing actively to create cooperative movement in the Sivasagar district of Assam within a very short period.

\subsubsection{Cooperative fish farming societies:}

There are more than 450 nos. Primary Fishery Cooperatives with one Apex Level Federation (FISHFED) functioning in the State. The Society is organised to help the poor fisherman community who are economically backward scheduled caste people for their socio-economic development. Table 3 reflects the district-wise registered cooperative fish farming societies of Assam. The Table reflected that Morigaon district had highest no of registered fishery cooperatives and Karmganj district had lowest no of fishery cooperatives in the state. The no of registered members under fish farming cooperatives was found highest in Morigaon district as highest no of fishery cooperatives were found in the district. On the other hand lowest fish farming cooperatives were observed in Karimganj district but members' registration was observed to be second highest after Morigaon district. It reflected that human resource involvement and livelihood generation by fishery cooperatives was found high in Morigaon and Karimganj districts with 5645 and 5188 member families working in this sector.

Assam has 216 nos of identified fish species having ornamental value in 50 nos with global demand.

\subsubsection{Cooperative sugar mills:}

The status of the cooperative sugar mills is not impressive in the state of Assam. The Assam Cooperative Sugar Mills Ltd was the $1^{\text {st }}$ sugar mill in Assam and was established in 1958 at Barua Bamungaon of Golaghat. The second cooperative sugar mill was Nagaon Coop: Sugar Mill of Kampur. Presently both the sugar mills are under liquidation. Miss management and less availability of proper technical support reflected as the main reason of liquidation of both the industries.

\subsubsection{Area, Production and Average Yield of Sugarcane in Assam}

Table 5 reflects the area, production and average yield of Sugarcane in Assam. It is observed that area and production of sugarcane was found to be increasing from 2007-08 to 2015-16. The increase production of sugarcane reflects the scope of development of sugar factory in the state. With the establishment of cooperative sugar factory in the state we can secure the income of the sugarcane farmer and also can develop livelihood generation for better future.

\subsubsection{Cooperative jute mill:}

The Assam Co-operative Jute Mills Ltd. was situated on the south bank of the river Brahmaputra at Silghat in the Nagaon district of Assam. It was registered in the year 1959 under the Assam Co-operative Societies Act and after much struggle it was commissioned in the year 1970 with the initial investment of Rs. 150 lakh. The Mill after running for about 14 years in rough weather had to close during March 1984 for acute financial crisis and other infrastructural problems and remain closed for about 2 years. Again, the Mill was reopened on 1st January 1986, under the terms of the Historic Assam Accord with the financial assistance from the Central Govt. as well as State Govt. Organization making continuous profits from the year 1992-93. Now, the Mill is completely free from all loans and liabilities and now it is in a stable economic position. 


\subsubsection{Area, Production and Average Yield of Jute in Assam}

Table 6 reflected the growth of area and production of Jute in the state of Assam. With increase growth of production of Jute a better chance of establishment of cooperative jute mill was observed in the state. Jute is important for making gunny bags; carpet, hessian cloths etc which are very demanding in the present day situation and that will be a good income generating activity for the people of Assam.

\subsubsection{Weavers \& artisan cooperative societies:}

The entire handloom industry comes under the umbrella of Ministry of Textiles; National Handloom Development Corporation Limited at the central level, Directorate of Handlooms and Textiles Development Corporation, The Assam State Handloom Weavers' Cooperative Society Limited at state level and Primary Weavers' Cooperative Societies at village level. Weavers' Cooperative Societies were found to be registered under the respective Office of the Handloom and Textiles, Government of Assam in each district. Membership strength of the Weavers' Cooperative Societies was found to be ranged from 100 to 250 members. (2)

There are more than 3,000 primary weavers' cooperative societies functioning in the state. Weavers' cooperative societies were producing Gamusa (Towel), Mekhla, Chaddar and Mekhla- Chaddar set (traditional dress worn by Assamese women), with blouse piece, Riha (upper garment worn by women), Saree, Blouse Piece, Door mat, Men's Kurta, Lady's Kurta, Salwar Kameez, Handkerchief and Stole. Shawl, Cushion cover, Bag and Table mat Tongali (piece of cloth worn by men during Bihu Dance), Table Runner, Curtain fabrics, Bed sheet, Dhoti and Shirts. Cotton was the most common yarn used by all the societies. Silk (mulberry, muga, eri and tassar), Rayon, Polyester, Acrylic yarn and Zari were also found to be recorded for used by many societies.

Assam Apex Weavers \& Artisans Co-operative Federation Ltd. (ARTFED) was formed on 27th July 1977 by reorganizing the Assam Apex Weavers Co-operative Society Ltd. with the aims and objects that the Apex Society shall organize Handloom Weaving and other Cottage Industries in the state on Co-operative basis. The Federation has now 16 districts and 988 number of primary level Co-operative as its members.

\subsubsection{Current Status of Cooperative Business in Assam}

Table 7 reveals the current status of Cooperative business in Assam. It was observed from the table that no of functional societies in the state decreasing from 10134 nos in the year 2005-06 to 8422 nos in the year 2012-13. Members' registration was observed to be almost stagnant throughout the period from 2005-06 to 2012-13. There was no vast change was observed in share capital contribution by cooperatives from the year 2005-06 to 2012-13. The working capital was observed to be increasing throughout the years as govt funding was continuously offered to societies for development of financial strength through various schemes. Due to lack of proper knowledge and miss management most of the cooperatives are not functional and few cooperatives are running under sick situation which requires adequate financial help from the Govt or other financial organizations for survival.

\section{INDENTATIONS}

The basic intent of the study is to have an overview of present and future status of producers' cooperatives in livelihood generation of Assam. The study is carried out to understand the magnitude of growth of cooperative sectors in Assam and to understand the issues need for further modification in the sector.

The study was based on primary as well as secondary data available in different literature extracted from different databases. This is a qualitative study intended to understand the issues related to status of producer cooperatives in livelihood generation of Assam, the structure, different players in the sector; the role played by different types of producer cooperatives and the success or failure of the societies in the state.

\section{FIGURES AND TABLES}

Table1 Employment in Organized Sector

\begin{tabular}{ll}
\hline - & Public Sector (Govt.+Quasi+local ) \\
- & \% of Female in Public Sector \\
- & Government Sector (Central + State) \\
- & Quasi \& Local Bodies \\
- & \% of Femal in Private sector \\
- & Cooperative Sector (Direct + Self Employed) \\
- & Credit Cooperatives
\end{tabular}

\begin{tabular}{ccc}
$\mathbf{2 0 0 8}$ & $\begin{array}{c}\text { (in million) } \\
\mathbf{2 0 1 0}\end{array}$ & \% change \\
\hline 17.674 & 17.862 & 1.06 \\
17.20 & 17.89 & \\
9.910 & 9.905 & \\
7.764 & 7.957 & \\
9.875 & 10.846 & 9.83 \\
25.03 & 24.55 & \\
16.69 & 17.80 & 6.65 \\
0.483 & 0.416 &
\end{tabular}




$\begin{array}{llcc}\text { - } & \text { Non Credit Coops \& Others } & 0.733 & 0.799 \\ \text { - } & \text { Self- Employed in Cooperatives** } & 15.47 & 16.58\end{array}$

Source: Indian Cooperative Movement- A statistical profile 2012.(5)

** Self employment comprises $70 \%$ active membership of Dairy, Farming, Weavers, Industrial, Fisheries, Poultry, Labour, Forest Labour \& Tree Growers and Transport Cooperatives.

Table 2 Share of Cooperatives in Indian Economy:

\begin{tabular}{lll}
\hline \multicolumn{2}{l}{ Indicator } & $\%$ \\
\hline - & Agricultural Credit disbursed by Coop & 18 \\
- & Fertilizer disbursed & 36 \\
- & Fertilizer Production & 27 \\
- & Sugar production & 47 \\
- & Wheat Procurement & 34 \\
- & Milk Production & 80 \\
- & Oil Marketed & 49 \\
- & Warehouses & 64 \\
- & Fandlooms in Cooperatives & 54 \\
- & Rubber procured and Marketed & 23 \\
- & Direct employment generation & 18 \\
- & Self employment generation & 1.22 million \\
\hline
\end{tabular}

Source: Directorate of cooperative development, IFFCO, India. (7)

Table 3 Number of Primary Level Fisheries Co-operative Societies (Distrcit Wise) of Assam

\begin{tabular}{cccc}
\hline S1 no & District & No of Societies & Total members \\
\hline 1 & Barpeta & 21 & 1697 \\
2 & Bongaigaon & 10 & 1813 \\
3 & Cachar & 10 & 2186 \\
4 & Darrang & 6 & 586 \\
5 & Dhemaji & 9 & 1593 \\
6 & Dhubri & 7 & 424 \\
7 & Dibrugarh & 8 & 1578 \\
8 & Goalpara & 13 & 2455 \\
9 & Golaghat & 14 & 1563 \\
10 & Hailakandi & 6 & 1119 \\
11 & Jorhat & 15 & 3792 \\
12 & Kamrup & 28 & 4505 \\
13 & Karimganj & 2 & 5188 \\
14 & Kokrajhar & 3 & 358 \\
15 & Lakhimpur & 23 & 1772 \\
16 & Morigaon & 38 & 5645 \\
17 & Nagaon & 15 & 766 \\
18 & Nalbari & 4 & 761 \\
19 & Sivasagar & 10 & 1432 \\
20 & Sonitpur & 5 & 2878 \\
21 & Tinsukia & 5 & 734 \\
22 & Udalguri & 9 & 549 \\
\hline
\end{tabular}

Source: FISHCOPFED

Table 4 Fish Seed and Fish Production in Assam in the last five years

\begin{tabular}{lll}
\hline year & $\begin{array}{l}\text { Fish Seed } \\
\text { Production(In } \\
\text { Million Nos.) }\end{array}$ & $\begin{array}{l}\text { Fish Production } \\
\text { (In lakh Ton) }\end{array}$ \\
\hline $2011-12$ & 4490 & 2.43 \\
$2012-13$ & 4363 & 2.54 \\
$2013-14$ & 4546 & 2.67 \\
$2014-15$ & 5793 & 2.82 \\
$2015-16$ & 5995 & 2.97 \\
\hline \hline
\end{tabular}

DOI: $10.9790 / 0837-2206108591$ 
Source: report of FISHERY SECTOR AT A GLANCE, ASSAM 2015-16

Table 5 Area, Production And Average Yield Of Sugarcane In Assam A : Area (in hect.) P : Production (in tonnes) Av : Average yield (in kg / hect.)

\begin{tabular}{lcccccccc}
\hline & $\mathbf{2 0 0 7 - 0 8}$ & $\mathbf{2 0 0 8 - 0 9}$ & $\mathbf{2 0 0 9 - 1 0}$ & $\mathbf{2 0 1 1 - 1 2}$ & $\mathbf{2 0 1 2 - 1 3}$ & $\mathbf{2 0 1 3 - 1 4}$ & $\mathbf{2 0 1 4 - 1 5}$ & $\mathbf{2 0 1 5 - 1 6}$ \\
\hline A & 25734 & 28649 & 27165 & 29736 & 28404 & 28871 & 29083 & 29900 \\
P & 979860 & 1099749 & 1062423 & 1076332 & 1052514 & 1028161 & 1075171 & 1099134 \\
AV & 38075 & 38387 & 39110 & 36196 & 37055 & 35612 & 36969 & 36760 \\
\hline \multicolumn{2}{l}{ Source: Directorate of Economics \& Statistics, Assam }
\end{tabular}

Table 6 Area, Production And Average Yield of Jute in Assam: A : Area (in hect.) P : Production (in tonnes) Av : Average yield (in $\mathrm{kg} /$ hect.)

\begin{tabular}{lllllllll}
\hline & 2007-08 & $\mathbf{2 0 0 8 - 0 9}$ & $\mathbf{2 0 0 9 - 1 0}$ & $\mathbf{2 0 1 1 - 1 2}$ & $\mathbf{2 0 1 2 - 1 3}$ & $\mathbf{2 0 1 3 - 1 4}$ & $\mathbf{2 0 1 4 - 1 5}$ & $\mathbf{2 0 1 5 - 1 6}$ \\
\hline A & 59842 & 60111 & 65270 & 62267 & 65560 & 65092 & 69822 & 70403 \\
P & 656821 & 647455 & 713294 & 625575 & 608023 & 557990 & 717261 & 767548 \\
AV & 1976 & 1939 & 1967 & 1808 & 1669 & 1543 & 1849 & 1962 \\
\hline
\end{tabular}

Source: Directorate of Economics \& Statistics, Assam

Table 7 Current Status of Cooperative Business in Assam

\begin{tabular}{lllll}
\hline year & No of societies & $\begin{array}{l}\text { Membership } \\
\text { (in '000 nos) }\end{array}$ & $\begin{array}{l}\text { Share capital } \\
\text { (Rs in core) }\end{array}$ & $\begin{array}{l}\text { Working capital } \\
\text { (Rs in core) }\end{array}$ \\
\hline $\mathbf{2 0 0 5 - 0 6}$ & 10134 & 4499 & 106.84 & 1393.30 \\
$\mathbf{2 0 0 6 - 0 7}$ & 10028 & 4473 & 120.90 & 1390.96 \\
$\mathbf{2 0 0 7 - 0 8}$ & 10150 & 4482 & 123.91 & 1394.54 \\
$\mathbf{2 0 0 9 - 1 0}$ & 7696 & 4608 & 112.56 & 2186.37 \\
$\mathbf{2 0 1 0 - 1 1}$ & 7906 & 4612 & 107.36 & 2724.29 \\
$\mathbf{2 0 1 1 - 1 2}$ & 8006 & 4600 & 98.35 & 2806.09 \\
$\mathbf{2 0 1 2 - 1 3}$ & 8422 & 4592 & 102.07 & 2812.66 \\
\hline
\end{tabular}

Source: Statistical Handbook of Assam, 2014 (6)

\subsection{PROBLEMS IDENTIFIED IN COOPERATIVES BUSINESS AND REMEDIES FOR IMPROVEMENT:}

The Cooperative sector in Assam facing various problems related to their production and management of their organization. Most of the cooperatives are functioning in breakeven point. As cooperative sector has the power for employment generation in the local youth, progress and survival of these kinds of organizations are very important for livelihood generation of the people of Assam.

Few highlighted points of problems identified in cooperative business in Assam:

- Lack of idea about new businesses and enterprises.

- Lack of involvement of technical person

- Over dependence on Govt.

- Fear for market failure

- Too much dependence on outside source of finance.

\subsection{REMADIES:}

$\Rightarrow$ Involvement of technical person and skill labour is very important for growth of a cooperative business.

$\Rightarrow$ Correct organizational structure and good management helps the organization to move in a right direction and to earn good amount of profit for development and survival of the business. 


\section{Organizational Structure required for success of a Producers' Cooperative:}

Chairman

Board of Directors

ת

Managing Director

Headş Def Depts

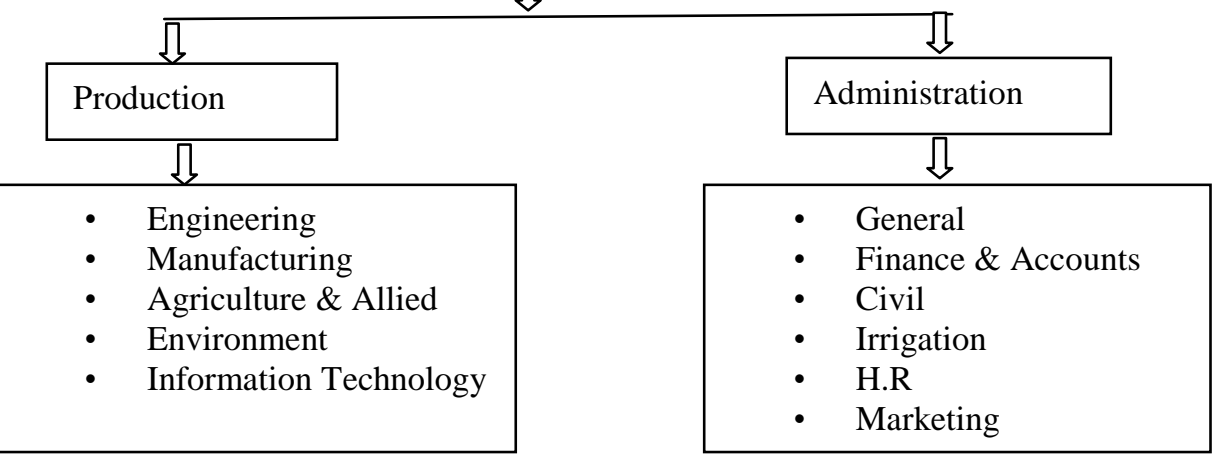

$\Rightarrow$ Production of quality fabrics, modernization of looms, creation of commercial motivation amongst the weavers, extension of training facilities, development of textile design etc. will bring changes to the weaver cooperative societies of Assam.

$\Rightarrow$ Assam has potential in development of cooperative business in Rice Milling and Flour Milling, oil mills, Biscuit manufacturing and Bakeries, Fruit processing especially Banana, Oranges, Litchi, Pineapple and Papaya, Fish processing, Tea leaves related processing for development of rural livelihood

$\Rightarrow$ Along with these few new ideas of business can be incorporated in cooperative sector for development of business on the basis of demand of the consumers. These includes:

1. Fish Clinic

2. Food Park

3. Restaurant

4. Organic farming and organic fertilizer production.

5. Packaging of traditional products

6. Commercial cultivation of high value crops like Strawberry and cashew nuts

7. Baby foods.

Cooperatives of Gujarat and Maharashtra were mostly found very successful due to maintenance of proper organizational structure and involvement of proper technical persons in the cooperative business. To create successful environment for cooperatives in Assam, Assam Rajiv Gandhi University of Cooperative Management, Sivasagar was established in the year 2010. The University is trying to produce technical persons suitable for development of cooperative movement in Assam. With involvement of proper technical persons and adoption of proper production technology cooperative sector of Assam will definitely be turn into a new direction.

\section{Journal Papers:}

\section{REFERENCES}

[1] Kumar V. Wankhed K.G. and Gena H.C. Role of Cooperatives in Improving Livelihood of Farmers on Sustainable Basis. American Journal of Educational Research, 3(10), 2015,1258-1266

[2] Baruah, R. R. Adachi and Kaur, S. A Study on analysis of Weavers' Cooperative societies in twelve selected districts of Assam, International Journal of Applied Research, 5(1), 2015, 232-234.

Books:

[3] National Dairy Development Board, Annual Report-2015-16, pp. 3-4

[4] Economic Survey, Assam 2012-13, chapter XV, Cooperation, 2013, 166-171.

[5] Indian Cooperative Movement- A statistical Profile 2012, 24

[6] Statistical Handbook of Assam, Published by Directorate of Agriculture, Govt. of Assam, 2014-15

Proceedings Papers:

[7] G.N Saxena, Supporting Local Development through Cooperatives- Indian perspective, IFFCO, India 123 